\title{
The influence of the microflora of the alimentary tract on protein digestion in the chick
}

\author{
By D. N. SALTER ANd MARIE E. COATES \\ National Institute for Research in Dairying, Shinfield, Reading $R G 29 A T$
}

(Received I3 May 1970-Accepted 2 February r97I)

\begin{abstract}
I. The course of digestion of freeze-dried and heat-damaged egg albumen labelled with ${ }^{14} \mathrm{C}$ in all its constituent amino acids was compared in germ-free and conventional chicks. The albumen was given at a level of $10 \%$ in a test meal containing $28 \%$ protein. Samples of digesta were taken $5 \mathrm{~h}$ later and analysed for ${ }^{14} \mathrm{C}$ and nitrogenous constituents.

2. After administration of unheated albumen, II \% of the ${ }^{14} \mathrm{C}$ remained in the germ-free gut, compared with $23 \%$ in the conventional gut. The poorer digestibility of the heat-damaged albumen was shown by recovery of 42 and $47 \%$ of the ${ }^{14} \mathrm{C}$ from the gut of germ-free and conventional birds respectively.

3. With both diets there was a higher ${ }^{14} \mathrm{C}:$ nitrogen ratio in the contents of the lower gut of conventional birds. Most of the $\mathbf{N}$ remaining in the gut was composed of protein or the hydrolysis products of protein, the amounts of which tended to be higher in the germ-free environment; urea and uric acid formed only a small proportion of the total N. There was less urea and more uric acid in the lower gut and excreta of conventional chicks.

4. It was concluded that microbial activity did little to increase the availability of protein to the chick. However, its effect on the nitrogenous material in the lower part of the alimentary tract might result in low recovery of $\mathrm{N}$ in the faeces and thus lead to erroneously high estimates of protein quality in tests with conventional chicks.
\end{abstract}

The presence of a large population of micro-organisms in the alimentary tract of conventional animals has given rise to considerable speculation as to how far microbial activity influences the course of digestion and metabolism of proteins, and whether the results are beneficial or detrimental to the host. One possibility is that amino acids released during digestion might be taken up by micro-organisms and thus rendered unavailable to the host. A second, proposed by Nesheim \& Carpenter (I967), is that proteins of dietary or endogenous origin that escape digestion in the small intestine might be catabolized by microbial enzymes in the lower gut, with subsequent absorption of the end-products. If the end-products were amino acids, or simple nitrogenous compounds (e.g. ammonia) from which non-essential amino acids could be synthesized, they might be of benefit to the host. Alternatively, they might be of no nutritional value as, for instance, biologically unavailable peptides: ammonia in excess would also be valueless. In the latter event the evaluation of protein quality by any test based on measurement of nitrogen retention would give spuriously high results.

In the germ-free animal nutritional processes can be studied in the complete absence of detectable microbes. By parallel studies on its conventional counterpart any modifications brought about by the action of the gut microflora can be detected. The work reported here forms the first part of an investigation into the role of micro-organisms in the digestion and metabolism of protein. The chick was chosen as the subject for these studies because it is relatively simple to produce and maintain germ-free. Further, unlike the rat, it does not develop enlarged caecums in a germ-free environ- 
ment nor does it practice coprophagy when kept on screen floors. Thus the interpretation of analyses of gut contents is not complicated by the accumulation of fluid in the lower bowel or by the presence of recycled diet. The chick has the disadvantage, however, that urine and faeces are excreted together so that partition of $\mathrm{N}$ between the two cannot be accurately estimated.

Little is known about protein digestion in germ-free animals, so that these experiments were necessarily of an exploratory nature. They were designed to give a broad picture of the course of digestion of a good- and a poor-quality protein in the presence and absence of the conventional gut microflora, and to indicate aspects of the problem which might merit more detailed study. Since the number, type and activity of the gut micro-organisms can be influenced by the diet and feeding pattern of the host, normal feeding conditions were followed as nearly as possible. The diet contained an optimal level of protein from a mixed source. Dried egg white formed part of the protein mixture because it could be generally labelled with ${ }^{14} \mathrm{C}$ in all its constituent amino acids and thus act as a marker for the protein moiety of the diet. Furthermore, by appropriate heat treatment the availability of its amino acids could be seriously reduced, permitting a comparison of the effects of the flora on good- and poor-quality protein without altering the composition of the rest of the diet.

A preliminary account of this work has been presented elsewhere (Salter \& Coates, 1970).

\section{MATERIALS AND METHODS}

\section{Chicks}

Chicks of the Rhode Island Red $\times$ Light Sussex cross were used. The eggs were incubated in a commercial incubator for $18 \mathrm{~d}$, then candled and disinfected with peracetic acid solution as described by Harrison (1969). Half were immediately introduced into Gustafsson germ-free isolators and half were replaced in the conventional incubator to hatch. After hatching, the germ-free birds were distributed in groups of five, in stainless-steel cages fitted with wire-screen floors inside the isolators. The conventional birds were housed in similar cages in a controlled-environment room where the lighting, temperature and humidity could be adjusted to match those inside the isolator. As far as possible males and females were distributed evenly throughout the experimental groups. At intervals during the experiment sterility checks as described by Fuller (1968) were made on the birds in the isolators.

\section{Diet}

The diet had the following percentage composition: egg albumen (see below) 10, vitamin-low casein (Fison's Pharmaceuticals Ltd, Loughborough) 9, gelatin 10, maize starch 60.25, salt mixture 6, L-cystine $0 \cdot 3$, choline chloride $0 \cdot 15$, inositol $O \cdot I$, vitamin supplement $0 \cdot 2$, maize oil 5 . In each $100 \mathrm{~g}$ diet the salt mixture provided $\mathrm{CaCO}_{3} \mathrm{I} \cdot 5 \mathrm{~g}, \mathrm{~K}_{2} \mathrm{HPO}_{4} \mathrm{I} \cdot 6 \mathrm{I} \mathrm{g}, \mathrm{CaHPO}_{4} \cdot 2 \mathrm{H}_{2} \mathrm{O}_{1} \cdot 37 \mathrm{~g}, \mathrm{NaCl} 0.837 \mathrm{~g}, \mathrm{MnSO}_{4} \cdot{ }_{4} \mathrm{H}_{2} \mathrm{O}$ $25 \mathrm{mg}$, KI $4 \mathrm{mg}, \mathrm{CuSO}_{4} \cdot{ }_{5} \mathrm{H}_{2} \mathrm{O} \mathrm{I} \cdot 5 \mathrm{mg}, \mathrm{ZnCl}_{2} \mathrm{I} \cdot 25 \mathrm{mg}$; the fat-soluble vitamins were dissolved in the maize oil to give, per roog diet, retinol 6800 i.u., cholecalciferol r6o i.u., menaphthone $500 \mu \mathrm{g}$, $\alpha$-tocopheryl acetate $\mathrm{r} \mathrm{mg}$; the vitamin supplement 
provided thiamin hydrochloride $1.2 \mathrm{mg}$, riboflavin $2.4 \mathrm{mg}$, calcium pantothenate $6 \mathrm{mg}$, pyridoxol hydrochloride $\mathrm{I} \cdot 6 \mathrm{mg}$, biotin $\mathrm{I} 60 \mu \mathrm{g}$, nicotinic acid $\mathrm{I} 6 \mathrm{mg}$, pteroylmonoglutamic acid $300 \mu \mathrm{g}$, cyanocobalamin $8 \mu \mathrm{g}$, in each $100 \mathrm{~g}$ diet. All the vitamin supplements were high to compensate for possible losses during sterilization; the biotin content was further increased since preliminary trials had shown that avidin had not been completely destroyed in the egg white.

After the diet had been mixed it was made into granules by moistening with water, pressing the paste through a B.S.S. no. 4 sieve and drying in a current of air below $45^{\circ}$. The dry diet was packed into plastic bags and sterilized by $\gamma$-radiation at $5 \mathrm{Mrd}$.

\section{Preparation of egg albumen}

The albumen used in the basal diet was prepared from fresh eggs. The whites were separated from the yolks, spread on stainless-steel trays and dried overnight in a current of air at $45^{\circ}$.

The method of preparation of ${ }^{14} \mathrm{C}$-labelled albumen proteins is described more fully elsewhere (Salter, Coates \& Westgarth, I97r); briefly, the procedure was as follows. Laying hens of the Light Sussex strain were injected, into the wing vein, with $0.5 \mathrm{mCi}\left[\mathrm{U}-{ }^{14} \mathrm{C}\right]$ protein hydrolysate from Chlorella (Radiochemical Centre, Amersham, Bucks). The injection was made within $6 \mathrm{~h}$ of oviposition, so that the albumen proteins in the second egg to be laid had a high specific activity; the specific activity decreased in each subsequent egg. Eggs were collected for about Io d after injection. The whites were separated from the yolks and individually freeze-dried. The whites of the second to the eighth eggs were mixed together to produce a sample of the required specific activity. Analysis of the labelled egg white in an EEL Automatic Amino Acid Analyser (Evans Electro-selenium Ltd, Halsted, Essex) showed that all the constituent amino acids except tryptophan (which was absent from the Chlorella protein hydrolysate) were labelled with ${ }^{14}$ (C.

\section{Preparation of heat-damaged egg white}

Heat-damaged egg white for the unlabelled diet was prepared from the air-dried powdered albumen by spreading it, in $250 \mathrm{~g}$ lots, in layers $0.5 \mathrm{~cm}$ deep on stainlesssteel trays $(38 \mathrm{~cm} \times 3 \mathrm{I} \mathrm{cm})$. The trays were covered loosely with aluminium foil with holes pierced in it at $5 \mathrm{~cm}$ intervals, and autoclaved in steam at $12 \mathrm{I}^{\circ}$ for $24 \mathrm{~h}$. After this treatment the moist cake was dried in an oven at $105^{\circ}$ until the weight was restored to its original value. The dry brown cake was reduced to a fine powder in a Christy-Norris Laboratory Hammer Mill. The freeze-dried ${ }^{14} \mathrm{C}$-labelled egg white was heat-treated in the same way.

\section{Collection of digesta}

The germ-free chicks were removed from the isolators immediately before collection of the digesta. The birds were anaesthetized with diethyl ether and an incision was made in the abdomen to expose the alimentary tract. The duodenum was isolated by a ligature placed close to the gizzard and another just proximal to the entry of the bile duct. It was cut just below the first ligature and a glass cannula was inserted and tied 
in place; a second cannula placed at the lower end of the duodenum was attached to a polyethylene tube leading into a plastic collecting vessel standing in ice. The upper cannula was connected to a reservoir of $0.85 \%(\mathrm{w} / \mathrm{v}) \mathrm{NaCl}$ solution at $38^{\circ}$ and saline was allowed to flow through the duodenum until the contents had been removed. The combined contents of jejunum and ileum were similarly washed out through cannulas inserted just distal to the bile duct and at the ileo-caecal junction. A glass cannula was then passed into the cloaca and tied into position; the contents of the caecums and colon were washed out through it by introducing warm saline into the tips of the caecums with a hypodermic syringe. At this stage the bird was killed with ether, the crop, gizzard and proventriculus were dissected out and their contents collected by washing out with saline.

In an experiment to determine the rate of crop-emptying, in the anaesthetized chick, artery forceps were placed across the oesophagus immediately above and below the crop. It was removed from the bird, the bulk of the contents was squeezed out through one end and the remainder washed out with distilled water.

When excreta were required for analysis they were collected at hourly intervals and immediately deep-frozen to minimize degradation after voiding. At the end of the experimental period samples from individual birds were pooled and evenly suspended in saline.

The resuspended gut contents and excreta were centrifuged at $17000 \mathrm{~g}$ for $25 \mathrm{~min}$ at ${ }^{\circ}$ in an MSE High-Speed $\mathrm{x} 8$ Centrifuge (Measuring and Scientific Equipment Ltd, London). The soluble fraction was decanted and stored at $-20^{\circ}$, the tubes were drained and the sedimented insoluble fraction was freeze-dried and stored under reduced pressure over phosphorus pentoxide at $5^{\circ}$.

\section{Measurement of radioactivity}

Duplicate samples of gut contents $(5-10 \mathrm{mg}$ dry weight of insoluble fraction or $0.5 \mathrm{ml}\left(0.05^{-1} \mathrm{mg} \mathrm{N}\right)$ of soluble fraction) were digested with $\mathrm{I} \cdot 0 \mathrm{ml}$ I M-hyamine hydroxide in methanol by shaking at $55^{\circ}$ until clear and then mixed with ro $\mathrm{ml}$ phosphor (0.3 g r,4-bis(5-phenyl-2-oxazolyl)-benzene, $4 \mathrm{~g}$ diphenyl oxazole, $80 \mathrm{~g}$ naphthalene, $430 \mathrm{ml}$ distilled anisole, $560 \mathrm{ml}$ distilled methoxy-ethanol). ${ }^{14} \mathrm{C}$ was measured by liquid $\beta$-scintillation counting in a Packard Tri-Carb Liquid Scintillation Spectrometer, Model 3003, using the internal standard technique.

\section{$N$ determination}

$\mathrm{N}$ was determined by a Kjeldahl micro-digestion procedure followed by measurement in a Technicon AutoAnalyzer (Technicon Instruments Co. Ltd, Chertsey, Surrey) of the ammonium sulphate formed (Ferrari, 1960).

\section{Approximate estimation of protein, peptides, and amino acids}

Samples of digesta were hydrolysed with $6 \mathrm{M}$-hydrochloric acid at $\mathbf{1 2} \mathrm{I}^{\circ}$ for $3 \mathrm{~h}$, neutralized and treated with the modified ninhydrin reagent of Moore \& Stein (1954). The leucine-equivalent of the colour produced by samples was calculated by reference 
to a standard response curve prepared with graded concentrations of leucine. No attempt was made to assess the possible contribution to this colour of amines or other ninhydrin-positive substances which may have been present.

\section{Other analytical methods}

Ammonia was determined by the microdiffusion method of Conway (1957). Urea was determined in the soluble fraction of the gut contents by the method of Marsh, Fingerhut \& Miller (1965) in a Technicon AutoAnalyzer. Uric acid was measured by the uricase method of Praetorius (1965). It was separated from the soluble fraction of the excreta for the measurement of ${ }^{14} \mathrm{C}$ in a column of Sephadex G-25 (Pharmacia (Great Britain) Ltd, London) using a buffer containing per 1: $7 \cdot 8 \mathrm{~g} \mathrm{NaH} \mathrm{NO}_{4} \cdot 2 \mathrm{H}_{2} \mathrm{O}$, ${ }_{14} .6 \mathrm{~g} \mathrm{NaCl}$, and $4 \mathrm{M}-\mathrm{NaOH}$ to bring the $\mathrm{pH}$ value to 7.6 . Nucleic acids were determined as described by McAllan \& Smith ( 1969 ). Total and available amino acids were determined in the unheated and heated egg white powders by the method of Ford $\&$ Salter ( I 966) using Streptococcus zymogenes.

\section{Design of experiments}

About twice as many birds were reared as were used in the tests. Although in general chicks grow better in a germ-free than in a conventional environment, the difference is not very great when a purified diet is given (Coates, r 968). No significant effect of environment on growth was observed in the present experiments. On the day of test, birds were selected from each environment so that their weights matched as closely as possible. An equal number of males and females were used in each series.

In experiments with undamaged protein (series $x$ ) the birds were reared to between $2 \mathrm{I}$ and $25 \mathrm{~d}$ of age on the basal diet containing air-dried egg albumen. They were then fasted overnight, and on the following morning were given a meal of $\mathrm{x} 0 \mathrm{~g}$ of the diet in which the air-dried unlabelled material had been replaced by an equal quantity of freeze-dried ${ }^{14} \mathrm{C}$-labelled egg white. The test meal was made into a paste by mixing with $10 \mathrm{ml}$ water and introduced directly into the crop by means of a syringe connected to a short length of plastic tubing. Samples of digesta were collected from four chicks $5 \mathrm{~h}$ after dosing.

A preliminary experiment was done to determine the rate at which the test meal, delivered as described, left the crop. Chicks were killed at intervals of $\mathrm{I}, 2,3,4$ and $5 \mathrm{~h}$ after receiving $10 \mathrm{~g}$ of the diet containing ${ }^{14} \mathrm{C}$-labelled egg white. The dry matter and ${ }^{14} \mathrm{C}$ remaining in the crop were determined on eight chicks at each time interval.

In the experiments with heat-damaged egg albumen (series 2) the birds were reared to $14 \mathrm{~d}$ of age on the diet with air-dried albumen. They were then transferred to a diet in which the air-dried albumen had been replaced by an equal quantity of the heatdamaged material. At the age of $24 \mathrm{~d}$ six birds were fasted overnight and given a test meal of Io $\mathrm{g}$ of diet containing ${ }^{14} \mathrm{C}$-labelled heat-damaged egg protein. Collections of digesta were made after $5 \mathrm{~h}$.

\section{Statistical methods}

The significance of the difference between means was analysed by Student's $t$ test. 


\section{RESULTS}

\section{Sterility checks}

All the isolators remained germ-free for the experimental period, with the exception of one which contained two birds used in the experiment on undamaged protein. At the last sterility check, taken a day before the test meal, contamination with Bacillus subtilis was detected. However, as the contaminant had appeared so late in the course of the experiment, and was an organism that does not become established in the alimentary tract, results for the two birds were included with those for the germ-free group.

\section{Experiment to determine rate of crop-emptying}

The rate of disappearance of ${ }^{14} \mathrm{C}$ and dry matter from the crop at hourly intervals after administration of $10 \mathrm{~g}$ of diet containing ${ }^{14} \mathrm{C}$ egg white is illustrated in Fig. I. The amount of diet in the crop decreased logarithmically, and after $5 \mathrm{~h}$ the crop was,

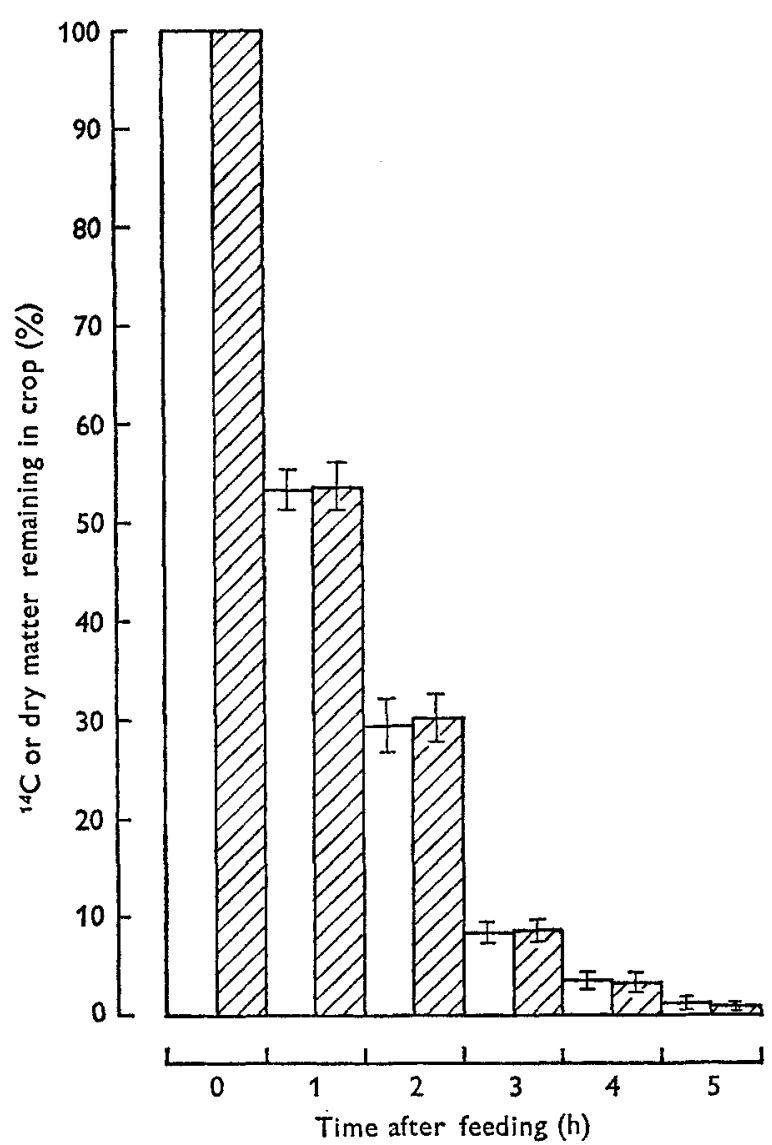

Fig. I. Rate of crop-emptying of conventional chicks given the diet containing unheated egg white. $\square,{ }^{14} \mathrm{C} ; \mathbb{\mathbb { N }}$, dry matter. The standard errors of the mean values are indicated by the vertical bars. 
for all practical purposes, empty. Comparison of the histograms shows that the proportions of ${ }^{14} \mathrm{C}$ and dry matter remaining in the crop agreed closely.

\section{Experiments with unheated and heat-damaged ${ }^{14} \mathrm{C}$-labelled egg white}

The contents of total and available methionine, leucine, isoleucine, histidine, valine and arginine in unheated and heat-damaged egg albumen are shown in Table $\mathrm{x}$. The availability for Streptococcus zymogenes of these amino acids was seriously reduced by the heat treatment. It was assumed that the other amino acids were similarly reduced in availability.

Table I. Availability of some amino acids in unheated and heat-damaged egg albumen $(g / 16 g N)$

\begin{tabular}{|c|c|c|c|c|c|c|}
\hline \multicolumn{2}{|c|}{ Methionine } & Leucine & Isoleucine & Histidine & Valine & Arginine \\
\hline Total in unheated egg albumen* & 4.09 & $9 \cdot$ II & $5 \cdot 47$ & $2 \cdot 45$ & $7 \cdot 08$ & 5.41 \\
\hline $\begin{array}{l}\text { Available in unheated egg } \\
\text { albumen } \dagger\end{array}$ & $3 \cdot 12$ & $8 \cdot 4 \mathrm{I}$ & NM & NM & NM & $\mathrm{NM}$ \\
\hline $\begin{array}{l}\text { Available in heat-damaged } \\
{ }^{14} \text { C-labelled egg albumen } \dagger\end{array}$ & $2 \cdot 06$ & $3 \cdot 75$ & $2 \cdot 29$ & 0.76 & $2 \cdot 94$ & $\mathrm{I} \cdot 76$ \\
\hline $\begin{array}{l}\text { Available in heat-damaged } \\
\text { unlabelled egg albumen } \dagger\end{array}$ & $I \cdot 84$ & 3.73 & $2 \cdot 12$ & 0.69 & $2 \cdot 62$ & $2 \cdot 15$ \\
\hline
\end{tabular}

The distribution and solubility of the ${ }^{14} \mathrm{C}$ and $\mathrm{N}$ remaining in the contents of different gut segments and in the excreta are shown in Table 2. Differences between the two environments were small and mostly non-significant. However, in both series of experiments there were slightly higher amounts of ${ }^{14} \mathrm{C}$ in the digesta and excreta of conventional birds, and a significantly greater proportion of ${ }^{14} \mathrm{C}$ and $\mathrm{N}$ in the soluble form in the lower gut of germ-free birds. A marked difference between the two proteins was apparent, with much more ${ }^{14} \mathrm{C}$ in the gut contents and excreta of chicks given the heat-damaged egg white. The livers of conventional and germ-free chicks given the undamaged egg white contained, respectively, 3.4 and $3.7 \%$ of the ${ }^{14} \mathrm{C}$ given.

Table 3 shows the ratio of ${ }^{14} \mathrm{C}$ to total $\mathrm{N}\left({ }^{14} \mathrm{C}: \mathrm{N}\right)$ in the gut contents and excreta. In both germ-free and conventional chicks, given either protein, the trend in ${ }^{14} \mathrm{C}: \mathrm{N}$ ratio from one segment to the next passing down the alimentary tract was similar. The most obvious difference between the two dietary treatments was the generally higher value of ${ }^{14} \mathrm{C}: \mathrm{N}$ ratio in samples from chicks fed on the heat-damaged protein, the value increasing in the intestines and caecums to well above that for the diet. Comparing results for the two environments, the value of ${ }^{14} \mathrm{C}: \mathrm{N}$ was higher in the jejunum + ileum, caecums + colon and excreta of the conventional than of the germfree chicks.

Where sufficient material was available, further analyses were done to investigate the composition of the nitrogenous material. The ninhydrin reaction with hydrolysed gut contents provided a rough measure of the combined protein, peptide and amino acid content of the digesta. The results for the soluble fractions from both series of 


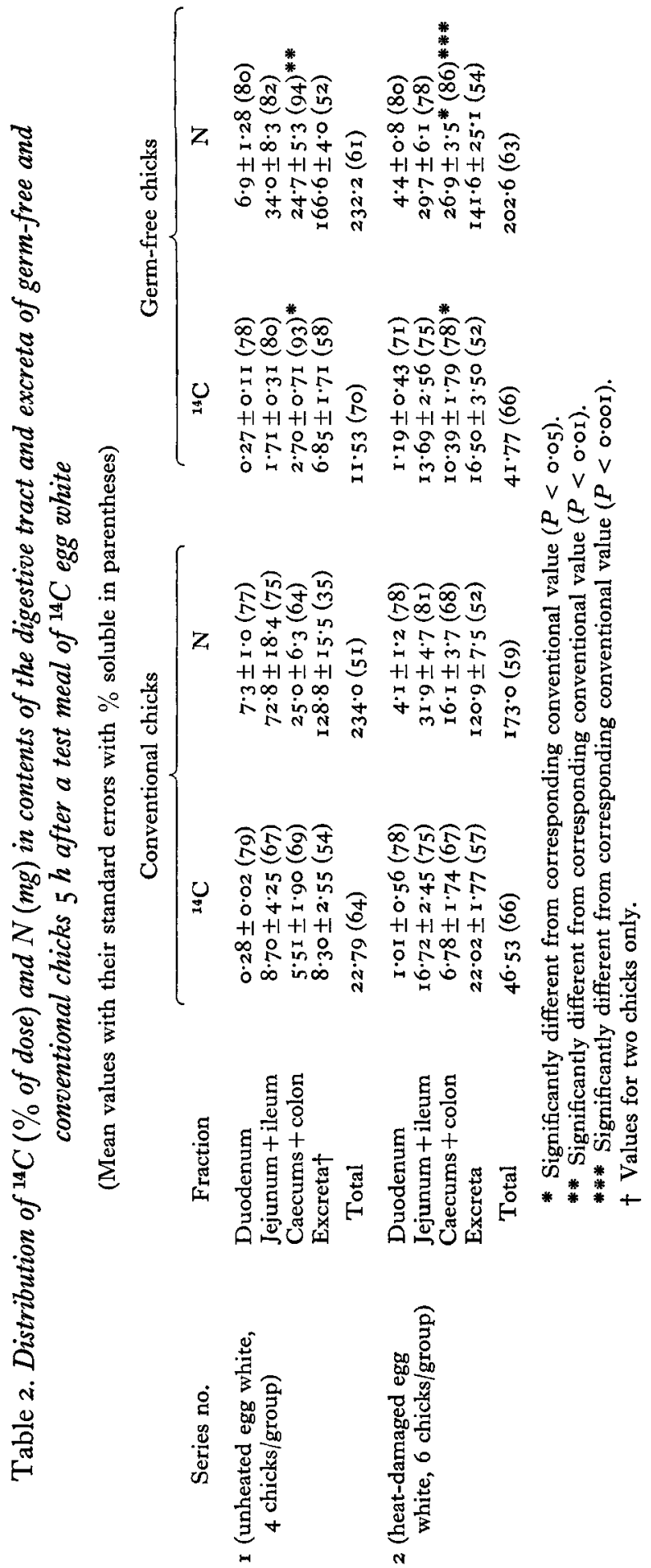


experiments and the insoluble fractions from series 2 are shown in Table 4. In general, the amount of ninhydrin-reacting material in each gut segment, expressed in terms of the leucine equivalent, paralleled the $\mathrm{N}$ content. Ratios of leucine equivalents to $\mathrm{N}$ in the gut contents were close to the measured values for the diets, in which the $\mathrm{N}$ was almost entirely in the form of protein. There was a greater excretion of ninhydrin-reacting material by the germ-free chick.

Table 3. Ratio of ${ }^{14} \mathrm{C}$ to total nitrogen in gut contents and excreta of chicks $5 h$ after a test meal of ${ }^{14} \mathrm{C}$ egg white $\left({ }^{14} \mathrm{C} \mathrm{dpm} \times \mathrm{IO}^{-3} / \mathrm{mg}\right.$ total $\left.\mathrm{N}\right)$

(Mean values with their standard errors)

\begin{tabular}{|c|c|c|c|c|}
\hline & \multicolumn{2}{|c|}{$\begin{array}{c}\text { Series I (unheated egg white, } \\
4 \text { chicks/group) }\end{array}$} & \multicolumn{2}{|c|}{$\begin{array}{c}\text { Series } 2 \text { (heat-damaged egg white, } \\
6 \text { chicks/group) }\end{array}$} \\
\hline & $\begin{array}{l}\text { Conventional } \\
\text { chicks }\end{array}$ & $\begin{array}{l}\text { Germ-free } \\
\text { chicks }\end{array}$ & $\begin{array}{l}\text { Conventional } \\
\text { chicks }\end{array}$ & $\begin{array}{l}\text { Germ-free } \\
\text { chicks }\end{array}$ \\
\hline${ }^{14} \mathrm{C}$ egg white & 10.59 & 10.59 & $18 \cdot 73$ & $18 \cdot 73$ \\
\hline Diet & 3.50 & 3.50 & 4.67 & $4 \cdot 67$ \\
\hline $\begin{array}{l}\text { Crop, proven- } \\
\text { triculus, gizzard }\end{array}$ & $3 \cdot 20 \pm 0.12$ & $3.20 \pm 0.02$ & $4.54 \pm 0.15$ & $4 \cdot 10 \pm 0.10$ \\
\hline Duodenum & $0.66 \pm 0.02 *$ & $0.70 \pm 0.31 \dagger$ & $4.03 \pm 0.95$ & $3.62 \pm 0.98$ \\
\hline Jejunum + ileum & $I .92 \pm 0.63$ & $0.99 \pm 0.27$ & $8.19 \pm 0.26 \neq$ & $7.72 \pm 0.85 t$ \\
\hline Caecums + colon & $3.57 \pm 0.43 \S$ & $2 \cdot 10 \pm 0.64$ & $6.60 \pm 0.84$ & $5.52 \pm 0.64$ \\
\hline Excreta & $I .07 \pm 0.31$ & $0.72 \pm 0.26$ & $2 \cdot 84 \pm 0.28$ & $I \cdot 8 I \pm 0.29$ \\
\hline $\begin{array}{l}\text { Excreta less } \\
\text { uric acid }\end{array}$ & \\
\hline \multicolumn{5}{|c|}{$\begin{array}{l}\text { dpm, disintegrations } / \mathrm{min} \text {. } \\
\text { * Significantly different from value for crop, proventriculus, gizzard }(P<0.01) \text {. } \\
\text { † Significantly different from value for crop, proventriculus, gizzard }(P<0.00 \mathrm{I}) \text {. } \\
\text { I Significantly different from value for duodenum }(P<0.0 \mathrm{I}) \text {. } \\
\text { \$ Significantly different from value for duodenum }(P<0.00 \mathrm{I}) \text {. } \\
\text { \| Significantly different from corresponding conventional values }(P<0.05) \text {. } \\
\text { ๆ Significantly different from corresponding conventional values }(P<0.0 \mathrm{I}) \text {. }\end{array}$} \\
\hline
\end{tabular}

Urea formed a very small part of the total soluble $\mathrm{N}$ (Table 5). There was less urea in the lower gut and excreta of conventional as compared with germ-free chicks, but the difference only reached the accepted level of significance in the caecums + colon of birds on the heat-damaged protein $\operatorname{diet}(P<0.01)$.

As there was insufficient material from the first experiment, the remaining analyses were done only on samples from birds given the heat-damaged egg white. A very small proportion of the total $\mathrm{N}$ in gut contents was contributed by uric acid in both environments (Table 6). There was, however, more uric acid in the lower gut and caecums of the conventional chicks. Uric acid formed a much higher proportion of the total $\mathrm{N}$ of the excreta of the conventional than of the germ-free chicks ( 38 and $29 \%$ respectively). In both environments the excreted uric acid, after separation on Sephadex G-25, was shown to be essentially free of ${ }^{14} \mathrm{C}$.

The amounts of nucleic acid $\mathrm{N}$ are shown in Table 7. The proportions of both RNA and DNA were considerably higher in the gut contents and excreta of the conventional chick than in those of its germ-free counterpart.

The composition of the nitrogenous material in the excreta of chicks fed on the heat-damaged egg white is summarized in Table 8. 


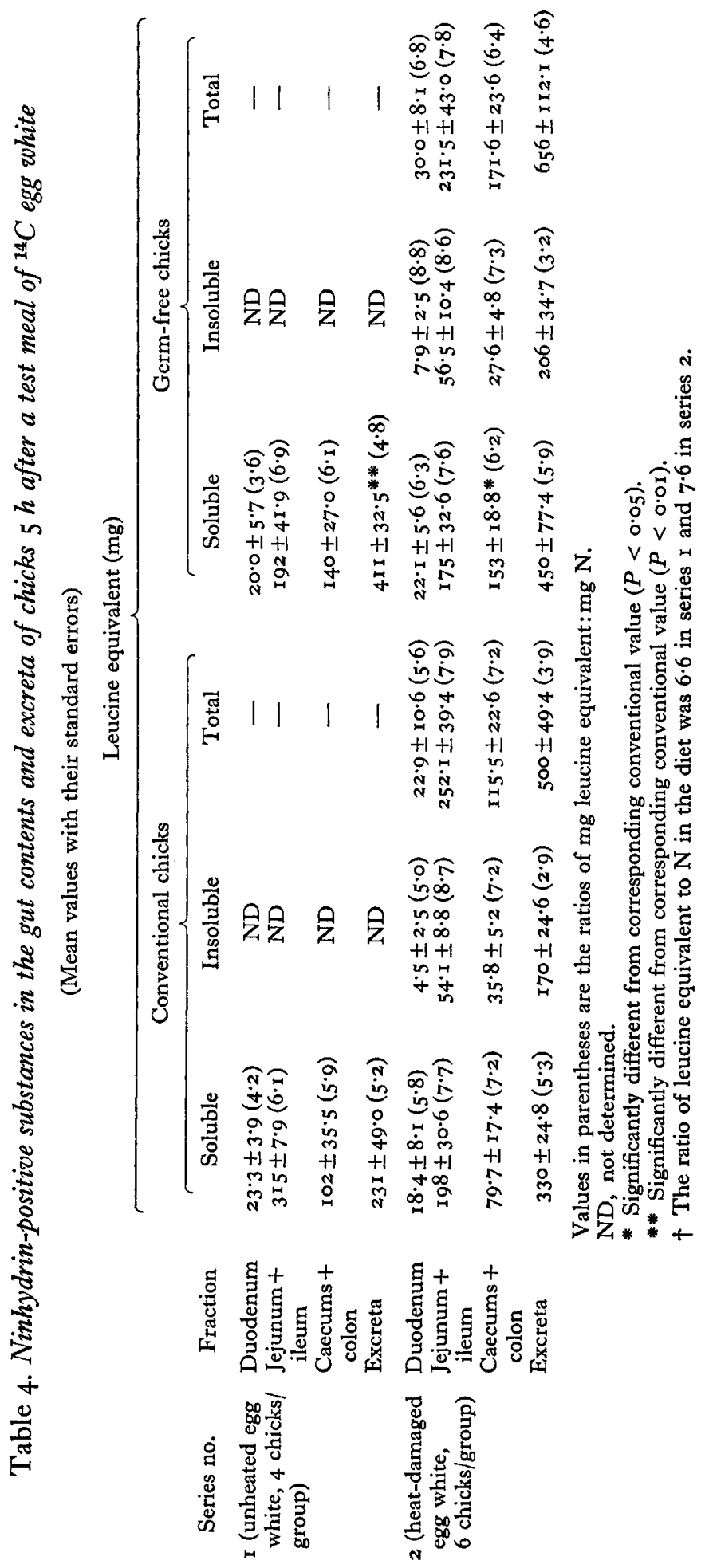


Table 5. Urea nitrogen $(\mu g)$ in the gut contents of chicks $5 h$ after a test meal of ${ }^{14} \mathrm{C}$ egg white

(Mean values with their standard errors)

Series I

(unheated egg white, 2 chicks/group)

Fraction

Duodenum

Jejunum + ileum

Caecums + colon Excreta

$\overbrace{\begin{array}{c}\text { Conventional } \\ \text { chicks }\end{array}}^{\begin{array}{c}\text { Germ-free } \\ \text { chicks }\end{array}}$

II $\pm 3 \cdot$ I

$55 \pm 28$

$163 \pm 146$

$983 \pm 517$
I6 6 6. I

$3^{8} \pm 6 \cdot 3$

$251 \pm 44$

$4230 \pm 1090$
Series 2

(heat-damaged egg white, 6 chicks/group)

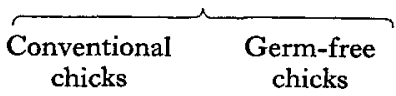

$3 \pm 0.03$

$0 \pm 0$

$14 \pm 6.3$

$2130 \pm 390$
$7 \pm 4 \cdot 5$

$14 \pm 6 \cdot 5$

$70 \pm 13 \cdot 8$

$2630 \pm 8$ 10

Significantly different from corresponding conventional value $(P<0.01)$.

Table 6. Uric acid nitrogen $(\mu g)$ in the gut contents and excreta of chicks 5 after a meal of heat-damaged ${ }^{14} \mathrm{C}$ egg white

(Mean values with their standard errors for six chicks)

Fraction

Duodenum

Jejunum + ileum

Caecums + colon

Excreta
Conventional chicks

$4 \cdot 1 \pm 0 \cdot 8$

$18 \cdot 9 \pm 3 \cdot 1$

$43.5 \pm 13.8$

$45900 \pm 5000$
Germ-free chicks

$3.2 \pm 0.9$

$13.4 \pm 2 \cdot 9$

$27 \cdot 0 \pm 12 \cdot 1$

$35400 \pm 4400$

Table 7. Nucleic acid nitrogen in gut contents and excreta of chicks

$5 \mathrm{~h}$ after a test meal of heat-damaged ${ }^{14} \mathrm{C}$ egg white

(Each result was determined on the pooled digesta of six chicks)

\begin{tabular}{|c|c|c|c|c|}
\hline \multirow[b]{3}{*}{ Fraction } & \multicolumn{4}{|c|}{ Nucleic acid $\mathrm{N}$ ( $\%$ of total insoluble $\mathrm{N}$ ) } \\
\hline & \multicolumn{2}{|c|}{ RNA } & \multicolumn{2}{|c|}{ DNA } \\
\hline & $\begin{array}{l}\text { Conventional } \\
\text { chicks }\end{array}$ & $\begin{array}{l}\text { Germ-free } \\
\text { chicks }\end{array}$ & $\begin{array}{l}\text { Conventional } \\
\text { chicks }\end{array}$ & $\begin{array}{l}\text { Germ-free } \\
\text { chicks }\end{array}$ \\
\hline $\begin{array}{l}\text { Jejunum + ileum } \\
\text { Caecums + colon }\end{array}$ & $\begin{array}{l}4 \cdot 7 \\
8 \cdot 9\end{array}$ & $\begin{array}{l}3 \cdot 7 \\
\times \cdot 8\end{array}$ & $\begin{array}{l}\mathrm{I} \cdot 6 \\
\mathrm{ND}\end{array}$ & $\begin{array}{l}0.6 \\
\text { ND }\end{array}$ \\
\hline Excreta & $I \cdot 4$ & 0.9 & 0.3 & 0.2 \\
\hline
\end{tabular}

\section{DISCUSSION}

The object of this work was to investigate how far the digestion and utilization of dietary protein is influenced by the resident microflora of the alimentary tract. The striking, and rather surprising, feature of the results was their general similarity in both the presence and absence of micro-organisms. The distribution of ${ }^{14} \mathrm{C}$ and $\mathrm{N}$ in the upper part of the alimentary tract was much the same in germ-free and conventional birds and it was only in the lower gut contents and excreta that any significant 
effect of environment was observed. This was true both for the good- and poorquality proteins although, as expected, the poorer digestibility of the heat-damaged egg white was very apparent.

Table 8. Composition of nitrogenous material (mg nitrogen) in excreta of chicks $5 h$ after a test meal of heat-damaged ${ }^{14} \mathrm{C}$ egg white

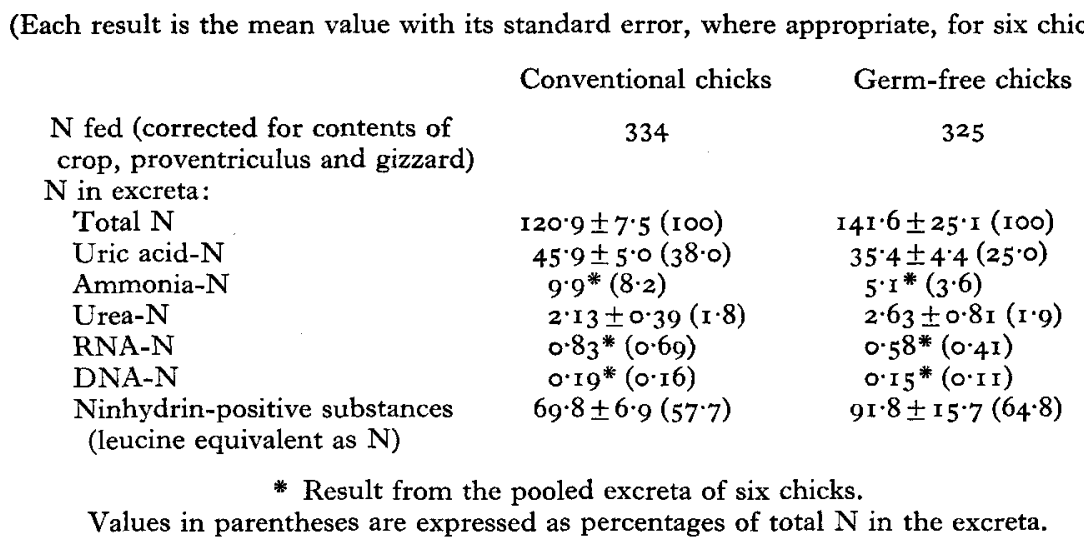

The use of ${ }^{14} \mathrm{C}$-labelled egg white was an attempt to distinguish between protein residues of dietary origin and those from endogenous sources. Nasset $\& \mathrm{Ju}$ (196r) used ${ }^{14} \mathrm{C}$-labelled casein in experiments to estimate the amounts of endogenous $\mathrm{N}$ in the intestines of dogs and rats, and it is implicit in the interpretation of their method that there was no separation of ${ }^{14} \mathrm{C}$ from $\mathrm{N}$. Hence a decrease in the ratio ${ }^{14} \mathrm{C}: \mathrm{N}$ relative to the diet was taken as an indication of dilution of dietary protein with endogenous N. Conversely, it was concluded that an increase from a low value indicated a greater rate of absorption of unlabelled nitrogenous material. However, this assumption may not be valid for conventional animals as separation of ${ }^{14} \mathrm{C}$ from $\mathrm{N}$ might be expected to occur under the influence of bacterial enzymes. In this event, absorption of ${ }^{14} \mathrm{C}$-containing groups would lead to a decrease in the ratio, and absorption or loss of nitrogenous material to an increase. It seems less likely that separation of ${ }^{14} \mathrm{C}$ from $\mathrm{N}$ would occur to any great extent in the germ-free intestinal contents, since amino acid transaminases, oxidases and dehydrogenases are characteristically intracellular enzymes. Also the presence of high deaminase or decarboxylase activities would appear to be contrary to the known function of the intestinal wall as a means of absorption and transport of amino acids. Thus comparison of the ${ }^{14} \mathrm{C}: \mathrm{N}$ ratio in the gut contents of germ-free and conventional chicks should give an indication of the extent of separation of ${ }^{14} \mathrm{C}$ from $\mathrm{N}$ caused by the microflora.

Measurements of ${ }^{14} \mathrm{C}$ in the different gut segments $5 \mathrm{~h}$ after the test meal showed that a high proportion of the good-quality protein had been digested, whereas almost half the ${ }^{14} \mathrm{C}$ from the heat-damaged egg white remained in the gut contents and excreta. With both types of protein, more ${ }^{14} \mathrm{C}$ was recovered from the digesta and excreta of conventional birds, from which it can be inferred that the microflora played little or no part in making the protein available to the host. The greater recovery of 
${ }^{14} \mathrm{C}$ from the gut contents of conventional birds, although not statistically significant, is indicative of two possible microbial effects. First, the conventional microflora may have decreased the absorptive capacity of the intestine, an idea compatible with the results of in vitro studies indicating poorer absorption of some nutrients from the small intestine of conventional compared with germ-free chicks (Ford \& Coates, 1971). Secondly, less ${ }^{14} \mathrm{C}$ may have been lost from the gut contents of the conventional birds owing to incorporation of the isotope into microbial cells.

The ${ }^{14} \mathrm{C}: \mathrm{N}$ ratio (Table 3 ) in samples from birds given unheated egg white differed little from the dietary ratio in the crop, proventriculus and gizzard. A very significant decrease in the duodenum indicates that the contents included a high proportion of unlabelled endogenous protein, probably contributed largely by pancreatic secretions. A tendency towards higher ratios in the lower gut suggests that reabsorption of some endogenous protein had taken place in the jejunum and ileum, leaving a residue of the least digestible part of the ${ }^{14} \mathrm{C}$-labelled protein. In the caecums and colon the ratio was considerably higher in conventional than in germ-free chicks, and it seems reasonable to suppose that bacterial deamination of amino acids was responsible, since the caecums are the site of greatest bacterial proliferation in the chick. In samples from the birds given heat-damaged egg white the ${ }^{14} \mathrm{C}: \mathrm{N}$ ratios followed a similar pattern but were very much higher and the increase between the duodenum and lower gut was highly significant. Although the ${ }^{14} \mathrm{C}$ measurements had shown that the damaged protein was incompletely digested after $5 \mathrm{~h}$, the unlabelled protein constituents of the diet had presumably been largely digested and absorbed. In consequence, the ${ }^{14} \mathrm{C}: \mathrm{N}$ ratios in some gut segments reached values very much higher than those in the original diet. The ratios, particularly in the lower gut and excreta, were consistently higher in samples from conventional birds, again suggesting that there had been microbial deamination. The suggestion was strengthened on further investigation into the composition of the nitrogenous constituents. On both diets, a lower $\mathrm{N}$ content of the soluble fractions in the caecums + colon and excreta of conventional chicks was reflected in a lower amount of ninhydrin-positive substances. This result could have arisen through bacterial destruction of amino acids, a possibility supported by the fact that in chicks given heat-damaged protein $6.7 \%$ of the soluble $\mathrm{N}$ in the conventional caecal contents was in the form of ammonia, compared with only $\mathrm{I} \cdot 2 \%$ in the germ-free sample.

Urea- $\mathrm{N}$ contributed very little to the total $\mathrm{N}$ in any of the samples. The generally lower amounts of urea- $\mathrm{N}$ in the digesta and excreta of conventional chicks can be attributed to the action of bacterial urease (Levenson, Crowley, Horowitz \& Malm, 1959; Ducluzeau, Raibaud, Dickinson, Sacquet \& Mocquot, 1966), and is in accord with findings in rats (Evrard, Hoet, Eyssen, Charlier \& Sacquet, 1964; Combe, Penot, Charlier \& Sacquet, 1965). Uric and nucleic acids were determined only in samples from chicks on the heat-damaged protein diet. Nucleic acid $\mathrm{N}$ made up $9 \%$ of the insoluble $\mathrm{N}$ in the conventional caecal sample and must have been mainly of microbial origin, whereas the $2 \%$ found in the corresponding germ-free sample presumably derived from mucosal cell debris. Uric acid accounted for only a small part of the total $\mathrm{N}$ in the gut contents and no important differences were seen between chicks 
reared in the two environments. The uric acid in the caecums and colon is likely to have been largely of urinary origin (Akester, Anderson, Hill \& Osbaldiston, 1967), but it is possible that in conventional chicks some may have resulted from catabolism of bacterial nucleic acids. The higher excretion of uric acid by the conventional birds is an indication that some absorption of microbially liberated ammonia had occurred.

The general conclusion is that, under the conditions of these experiments, the gut microflora had only a small effect on the products of digestion of protein in the upper part of the alimentary tract, but had a major influence in the lower gut and excreta. Even when part of the dietary protein was of poor quality, there was no evidence that its availability to the bird was improved by microbial action. However, the experiments were of short duration and the diet had a generous protein content. In these circumstances, the small differences that were indicated between the two environments in the absorption of amino acids are unlikely to have been of importance in the protein nutrition of the bird. Whether or not they would have been nutritionally significant on diets of less than adequate protein content remains to be investigated in longer-term studies. In the lower gut and excreta, residues of protein digestion were markedly different in the two environments. It is conceivable that some of the ammonia released by microbial action could, if absorbed, have been utilized by the bird for synthesis of non-essential amino acids. Again such an effect, if it existed, would not have been detectable on a good diet but might become apparent with a low-protein intake. Even though the products of microbial action in the lower gut may be of little consequence to the host, they could be important in biological tests where the proportion of dietary $\mathrm{N}$ apparently retained by the test animal (i.e. the difference between the amount eaten and the amount excreted) is used as a measure of the nutritive value of the protein. In the trials with both good- and poor-quality proteins the total $\mathrm{N}$ measured in the excreta of conventional chicks was less than in corresponding samples from germ-free birds. Although the difference was not statistically significant in these experiments, there were other strong indications that microbial deamination had taken place in the conventional birds and that all the liberated ammonia was not present in the excreta. Thus it seems that the faecal component of the $\mathrm{N}$ excreted by the germ-free birds was more truly representative of the residues of protein digestion.

Two groups of workers have used caecectomized chicks in attempts to throw light on the possible influence of micro-organisms of the lower gut on protein digestion. Both reported a higher apparent digestibility in intact than in caecectomized birds, but offered different explanations. Payne, Combs, Kifer \& Snyder (1968) considered that the intact birds might derive benefit from amino acids released by bacterial lysis of endogenous protein in the caecum. Nesheim \& Carpenter ( 1967$)$ postulated that, as a result of microbial action on undigested protein entering the caecum, nitrogenous compounds of no nutritional value might be produced and then absorbed. Our own findings lend strong support to the latter postulate and corroborate the suggestion that the value found for digestibility in intact birds was erroneously high. Final confirmation of this hypothesis awaits the results of $\mathrm{N}$ balance studies, now in progress, in germ-free and conventional birds. 
We are grateful to $\mathrm{Dr} \mathrm{J}$. W. G. Porter for his helpful interest and advice and to Dr D. J. Jayne-Williams for carrying out sterility checks on the germ-free birds. We also thank Mr A. B. McAllan for the determinations of nucleic acids in digesta, Mr K. J. Scott for the microbiological assays of available amino acids in the egg albumen preparations and $\mathrm{Mr} \mathrm{J}$. P. Fordham for care and maintenance of the germfree birds.

\section{REFERENCES}

Akester, A. R., Anderson, R. S., Hill, K. J. \& Osbaldiston, G. W. (1967). Br. Poult. Sci. 8, 209.

Coates, M. E. (1968). In The Germ-free Animal in Research p. 84 [M. E. Coates, editor]. London and New York: Academic Press.

Combe, E., Penot, E., Charlier, H. \& Sacquet, E. (1965). Annls Biol. anim. Biochim. Biophys. 5, 189.

Conway, E. J. ( I 957). Microdiffusion Analysis and Volumetric Error $4^{\text {th }}$ ed. London: Crosby Lockwood and Son Ltd.

Ducluzeau, R., Raibaud, P., Dickinson, A. B., Sacquet, E. \& Mocquot, G. (1966). C. r. hebd. Séanc. Acad. Sci., Paris 262, 944.

Evrard, E., Hoet, P. P., Eyssen, H., Charlier, H. \& Sacquet, E. (1964). Br. F. exp. Path. 45, 409.

Ferrari, A. (1960). Ann. N.Y. Acad. Sci. 87, 792.

Ford, D. J. \& Coates, M. E. (1971). Proc. Nutr. Soc. 30, 10A.

Ford, J. E. \& Salter, D. N. (I966). Br. F. Nutr. 20, 843 .

Fuller, R. (I968). In The Germ-free Animal in Research p. 37 [M. E. Coates, editor]. London and New York: Academic Press.

Harrison, G. F. (1969). Lab. Anim. 3, 5 1.

Levenson, S. M., Crowley, L. V., Horowitz, R. \& Malm, O. J. (r959). F. biol. Chem. 234, 206r.

McAllan, A. B. \& Smith, R. H. (I969). Br. F. Nutr. 23, 671.

Marsh, W. H., Fingerhut, B. \& Miller, H. (1965). Clin. Chem. II, 624.

Nasset, E. S. \& Ju, J. S. (r96r). F. Nutr. 74, 46 I.

Moore, S. \& Stein, W. H. (1954). F. biol. Chem. 211, 907.

Nesheim, M. C. \& Carpenter, K. J. (I967). Br. J. Nutr. 2I, 399.

Payne, W. L., Combs, G. F., Kifer, R. R. \& Snyder, D. G. (1968). Fedn Proc. Fedn Am. Socs exp. Biol. 27, I 199.

Praetorius, E. (x965). In Methods in Enzymatic Analysis p. 500 [H. U. Bergmeyer, editor]. New York and London: Interscience Publishers.

Salter, D. N. \& Coates, M. E. (1970). Proc. int. Congr. Nutr. virt. Prague, 1969 p. 425.

Salter, D. N., Coates, M. E. \& Westgarth, D. R. (I97I). Br. Poult. Sci. (In the Press.) 